\title{
A New Approach to Teaching Roman Art History
}

\author{
Marice Rose \\ Fairfield University, mrose@fairfield.edu
}

Follow this and additional works at: https://digitalcommons.fairfield.edu/visualandperformingartsfacultypubs

Copyright 2016 Johns Hopkins University Press for Classical Association of the Atlantic States. Archived here with permission from the copyright holder.

\section{Peer Reviewed}

\section{Repository Citation}

Rose, Marice, "A New Approach to Teaching Roman Art History" (2016). Visual \& Performing Arts Faculty Publications. 38.

https://digitalcommons.fairfield.edu/visualandperformingarts-facultypubs/38

\section{Published Citation}

Rose, Marice. "A New Approach to Teaching Roman Art History." Classical World 110.1 (2016): 119-136.

This item has been accepted for inclusion in DigitalCommons@Fairfield by an authorized administrator of DigitalCommons@Fairfield. It is brought to you by DigitalCommons@Fairfield with permission from the rightsholder(s) and is protected by copyright and/or related rights. You are free to use this item in any way that is permitted by the copyright and related rights legislation that applies to your use. For other uses, you need to obtain permission from the rights-holder(s) directly, unless additional rights are indicated by a Creative Commons license in the record and/or on the work itself. For more information, please contact digitalcommons@fairfield.edu. 


\title{
A New Approach to Teaching Roman Art History
}

\author{
MARICE ROSE
}

ABSTRACT: This article describes an approach to teaching ancient Roman art using historical empathy and current world events to foster students' engagement with, and learning about, both ancient Roman art and, more broadly, the power of art. This pedagogical approach can inspire richer understanding and increased motivation to learn, while offering possibilities for civic engagement. The suggestions may be helpful for secondary or college-level teachers of Roman art, and for classics teachers who incorporate ancient visual culture.

\section{Teaching Roman Art History ${ }^{1}$}

The first time I taught a Roman art course, I organized the class in the typical linear manner, as a chronological march through history. The class began with Etruscan and pre-Roman Italian art, and then considered republican art, focusing primarily on elite domestic decoration in Pompeii and veristic portraiture. Most of the semester was dedicated to imperial art, with discussions primarily of canonical, imperially commissioned monuments in Rome. The progression was punctuated by occasional short lessons on art from the nonelite realm and from the

${ }^{1}$ A version of this article was first presented at the Humanities and Education Research Association's 2014 Annual Meeting in Washington, D.C. I am grateful to Julie Mughal and Ana Siscar of Fairfield University's Jesuit University Humanitarian Action Network chapter for encouraging my pedagogical changes and suggesting resources, and to my Art History colleagues and students for their openness to my pedagogical experiments. I also owe thanks to Sharon James for sharing materials from her 2012 New York University Faculty Resource Network seminar "Talking Tough Topics through the Classics," and for sharing her then forthcoming chapter on teaching about rape, which has since been published: "Talking Rape in the Classics Classroom: Further Thoughts," in N. S. Rabinowitz and F. McHardy, eds., From Abortion to Pederasty: Addressing Difficult Topics in the Classics Classroom (Columbus 2014) 171-86. 
provinces, and images of women. The emphasis, however, remained on Rome's "grandeur, its relative uniformity, its longevity, and its positive impacts in bringing to new areas . . the entity called classical civilization," as David Mattingly characterizes ancient Rome's conventional metanarrative. ${ }^{2}$ While teaching the course, I sensed a lack of student engagement that perhaps mirrored my own. As a feminist scholar of images of women and the disenfranchised and of classical reception, I was frustrated by my difficulty integrating noncanonical material into the course's traditional foundational content knowledge. I wanted to heed Natalie Boymel Kampen's call for histories of Roman art to better engage multiple social categories, including gender and class, while discussing both the creation and reception of visual culture. ${ }^{3}$ I also felt a sense of duty to teach Roman imperial art's relationships to slaves and subject individuals from conquered territories in light of contemporary social justice issues, but did not know how to do this responsibly.

My teaching goals therefore adjusted the next time the class was taught. The previous goals- "Students will learn major Roman monuments in terms of period, place, significance, and by and for whom they were made; students will know relevant historical events and be able to use art-historical and architectural terms correctly; students will gain a broader understanding and appreciation of art"-were retained. I then added goals: "Students will know the importance and power of visual culture in the lived experiences of individuals from a wide spectrum of ancient Roman society; Students will understand the consequences of Roman imperialism on those individuals, and how these consequences were reflected or constructed by art." A more distant, less measurable aim was that students become more aware, and potentially engaged, citizens. By changing the course's goals-and therefore its organization and activities - to more fully incorporate a variety of social categories, to consider viewer reception, and to examine course material related to ancient and contemporary justice issues, student engagement improved. Class discussions, written work, and end-of-semester reflections showed that students were better able to make connections with the material,

${ }^{2}$ D. Mattingly, Imperialism, Power, and Identity: Experiencing the Roman Empire (Princeton 2011) xxii.

${ }^{3}$ N. B. Kampen ("On Not Writing the History of Roman Art,” ABull 77 [1995] 375 n.4) acknowledges the difficulties of writing such a history for students, because the linear way is most accessible to novices. 
and therefore cared more about it. As one student wrote, "This approach to learning brings the student closer to Roman history and to civilization as a whole."

\section{Class Logistics}

The course was one with no prerequisites, and most students enrolled in it to fulfill the university's art distribution requirement. This meant that they did not have previous knowledge of Roman art's contexts or chronology, which are necessary before art history is approached either thematically or empathetically. It was also crucial that students taking this as an art history course should learn about the grandeur and inventiveness of Roman built environments, the beauty and expressiveness of Roman statuary, the illusionistic subtleties of Roman fresco paintings, and the detail and delicacy of Roman metalwork. Therefore, the first six weeks of class introduced a chronologically thematic survey of Roman art within the context of historical events, social structure, religion, and domestic life (see appendix). Art-historical vocabulary, mediums, and techniques were introduced, as were specifically Roman art forms such as triumphal arches and portrait busts. Students learned how to discuss style and formally analyze Roman portraiture and public works, domestic and religious art and architecture, and funerary art (with attention to nonimperial commissions). Tests were given to ensure learning and retention. Units on war in art and on slavery in art followed, with discussions within those units of both ancient and modern state-sponsored portraiture, gender, children, and spectacles (see appendix for course schedule and readings). The units did overlap in certain areas, because for example many Roman slaves were obtained via war, so there was much cross-discussion. For textbooks, Eve D'Ambra's Roman Art and Roman Women and Sandra Joshel's Slavery in the Roman World work well as supplements to comprehensive Roman art textbooks like Fred Kleiner's, Steven Tuck's, or Nancy Ramage and Andrew Ramage's, because they are accessible for student readers and consider noncanonical art such as that from the provinces or relating to slaves, as well as art's role in constructing gender and class. ${ }^{4}$

${ }^{4}$ P. Stewart's Social History of Roman Art (Cambridge and New York 2008) is also valuable, although probably better suited for college students. 
Class discussion is important, whether deliberating the effects of a Roman artist's aesthetic choices, or big questions regarding the common good. In class, we sit in a circle facing one another to foster a sense of community. Students post responses to readings in an online journal (visible only to me), so they have time to process and reflect upon the material rather than skimming it immediately before class. Although I could have saved class time by assigning a documentary film on contemporary child slavery to watch at home rather than watching it in class, the communal experience was powerful as students were forced to give the film their complete attention. ${ }^{5} \mathrm{~A}$ challenging aspect to this emotional component of discussing slavery and war crimes (including sexual violence) is the possibility of making students uncomfortable if they have related personal experiences. ${ }^{6}$ There have been multiple valuable conversations at classics conferences and in print about teaching difficult topics that appear frequently in classical history, myth, and literature. ${ }^{7}$ The pedagogical literature includes a wide range of helpful advice, strategies, and classroom activities, with a large body concerning ancient references to, and descriptions of, rape in light of campus rape culture. ${ }^{8}$

The class was not a service-learning class; there were no required action or service components to meet my aim of students becoming more engaged citizens, but students were shown that they have agency and

\footnotetext{
${ }^{5}$ Assigning students reading (and requiring responses) rather than providing factual information in lectures freed up class time for this and other active learning activities.

${ }^{6}$ The current debate in popular media about "trigger warnings" in college classrooms began after the course was taught; see: J. Jarvie, "Trigger Warning," The New Republic, March 3, 2014, accessed May 14, 2015. http://www.newrepublic.com/article/116842/ trigger-warnings-have-spread-blogs-college-classes-thats-bad

${ }^{7}$ This was sparked by Sharon James's 2008 presentation on teaching rape in elegy at the Feminism/Classics V conference in Ann Arbor; see Rabinowitz and McHardy (above, n.1) $1-2$.

${ }^{8}$ It is not possible to summarize all here, but see S. James, "Feminist Pedagogy and Teaching Latin Literature," Cloelia 38 (2008) 11-14; G. Liveley, "Teaching Rape in Roman Elegy," and S. James, "Teaching Rape in Roman Love Elegy," in B. K. Gold, ed., A Companion to Roman Love Elegy (Malden,Mass., 2012) 541-48, 549-57. See also articles by R. Lauriola and D. Widdows in Cloelia's 2011 issue with a "Pedagogical Issues in the Classics" section on teaching sexual violence; articles on teaching rape by Y. Hong, E. Gloyn, and R. Lauriola in a thematic Paedagogus section in CW 106.4 (2013); Rabinowitz and McHardy (above, n.1), on homosexuality, slavery, and other "uncomfortable" topics. Many helpful resources (especially for primary and secondary-school educators) on teaching ancient and modern slavery with sensitivity are listed online; see the Gilder-Lehrman Center for the Study of Slavery, Resistance, and Abolition, "Teacher Resources," accessed May 14, 2015, http://www.yale.edu/glc/classroom/index.htm
} 
opportunities to help raise awareness and assist those in need if they chose to engage during the semester or in the future. I was fortunate in being able to access the resources of the Jesuit Universities Humanitarian Action Network (JUHAN), which has a chapter at my university. JUHAN, a collaboration of American and international Jesuit schools, was founded on the premises that academic institutions, when addressing the needs of those who are suffering, can be more effective if they work together, and that most American college students are ill-prepared for humanitarian action-whether they participate as a future career aid worker, or to fulfill civic responsibilities. ${ }^{9}$ Fairfield's JUHAN coordinator and program manager provided bibliography and advice on incorporating current events into my syllabus, and in addition there were several workshops and lectures throughout the semester on topics of humanitarian crisis and response. Students were required to attend at least one of these events of their choice. Some engaged in further action (I cannot fully credit the course for this); one student spent her spring break helping tornado victims in Joplin, Missouri; another attended an immersion trip to Washington, D.C., to meet with diplomats and politicians with regards to humanitarian aid; and another attended the annual JUHAN summer conference. One student reflected on the personal meaning of this experience: "Through linking these themes in Roman art to issues in the world today, I absolutely have a greater understanding and appreciation for issues that have persisted throughout human culture that need to be eliminated, even though they have occurred since the times of the Roman Empire and before."

\section{Historical Empathy as Pedagogical Tool and Learning Outcome}

The changes to the course can be categorized in pedagogical terms as using and promoting historical empathy. Historical empathy is one of the most discussed pedagogies of history education. ${ }^{10}$ Although historical

${ }^{9}$ Jesuit Universities Humanitarian Action Network, Fairfield University, accessed May 14, 2015. http://www.fairfield.edu/academics/schoolscollegescenters/academiccenters/ centerforfaithandpubliclife/preparingglobalcitizens/juhan/

${ }^{10}$ See S. Brooks, "Historical Empathy in the Social Studies Classroom: A Review of the Literature," JSSR 33 (2009) 213-34; J. L. Endacott, "Reconsidering Affective Engagement in Historical Empathy," TRSE 38 (2010) 6-47. 
empathy often involves "perspective recognition," (considering the perspectives of historical actors), there are many definitions of the term. Stuart J. Foster and Elizabeth Anne Yeager's influential article characterizes it as the ability to use inferential and creative skills, in combination with evidence and logic, to gain understanding of the past. ${ }^{11} \mathrm{O}$. L. Davis, Jr.'s version resonates with my practice: "Empathy characterizes historical thinking that yields enriched understanding within context. . . . It arises or develops from the active engagement in thinking about particular people, events, and situations in their context, and from wonderment about reasonable and possible meanings within, in a time that no one can really know." 12 The emphasis on the word "context" is significant. Research makes clear that using historical empathy successfully involves more than imaginative exercises that simply encourage the student to put him or herself in someone else's shoes, thereby promoting sympathy rather than empathy..$^{13}$ Careful analysis of context and evidence, as in the examples in section IV below, allows students to engage in historical inquiry as they consider art-making and viewing. ${ }^{14}$ My teaching goal, that students recognize the importance of art to more than elite ancient Romans, aligns with Karen Riley's encouragement of using historical empathy to consider ordinary individuals to whom students can relate. ${ }^{15}$ In teaching Roman art history, this means adding a broad range of images and visual evidence to the canonical monuments.

When using historical empathy as a component of teaching Roman art and history, especially in light of contemporary injustices, there is a probability that emotions will be elicited, as discussed above. The role of emotion is one of the most debated aspects of historical empathy. Although some warn that lessons should foster "cognitive" rather than

${ }^{11}$ S. J. Foster and E. A. Yeager, "The Role of Empathy in the Development of Historical Understanding,” IJSE 13 (1998) 1-7.

${ }^{12}$ O. L. Davis, Jr., "In Pursuit of Historical Empathy," in E. Davis, A. Yeager, and S. J. Foster, eds., Historical Empathy and Perspective Taking in The Social Studies (Lanham 2001) 3 .

${ }^{13}$ Imagining one's own self in a different situation prevents the recognition necessary for historical understanding that others viewed the world differently. See P. Lee and R. Ashby, "Empathy, Perspective Taking, and Rational Understanding," in Davis, Yeager, and Foster (above, n. 12) 21-50.

${ }^{14}$ S. J. Foster, "Historical Empathy in Thought and Practice: Some Final Thoughts," in Davis, Yeager, and Foster (above, n.12) 170.

${ }^{15}$ K. L. Riley, "Historical Empathy and the Holocaust: Theory into Practice," IJSE 13 (1998) 32-42. 
"affective," or "emotive," empathy, many educators including myself do not believe that education and emotion can or should always be separated, especially when studying history, or, I would argue, art. ${ }^{16}$ Keith Barton and Linda Levstik made a powerful and popular case for not rejecting affective components when asking students to consider perspectives of historical actors. They characterize making an emotional connection as caring, asking, "why would anyone want to attempt to study history without caring?" and emphasize its importance in humanistic study. ${ }^{17}$ Caring, when combined with evidence-based analysis, is important for students to become interested in a subject, motivated to study it, and willing to be challenged by it. ${ }^{18}$ One student reflected on this aspect: "I was genuinely interested in the subject matter. With this class, if I was confused about something, I tried to find the solution on my own because I truly wanted to know the answer. I wouldn't have done that if I wasn't interested in what I was learning."

As shown in the revised course goals, I felt a responsibility when teaching monuments celebrating or built with the gains of Roman imperialism and/or its slave system to raise students' awareness of contemporary humanitarian issues. Several scholars identify the paradox of historical empathy as being not only a tool for teaching students to care about the world around them, past and present, but also a desired outcome, long after the semester ends. ${ }^{19}$ In his article on using classical

${ }^{16}$ J. L. Endacott, "Reconsidering Affective Engagement in Historical Empathy," TRSE 38 (2010) 6-47; C. Blake, "Historical Empathy: A Response to Foster and Yeager," IJSE 13 (1998) 25-31. H. J. Garret and K. Greenwalt "“Confronting the Other: Understanding Empathy," CIE 13 [2010] 229) discuss teaching empathy in terms of critical emotion studies, a primary assumption of which is that emotions and reason are not discrete, but "intertwined in all decision-making processes."

${ }^{17}$ K. C. Barton and L. S. Levstik (Teaching History for the Common Good [Mahwah, N.J., 2004]) identify four important components of caring: caring about (historical interests); caring that (basis for our reactions to consequences of historical events), caring for (desire to help people in the past), and caring to (willingness to apply what has been learned in history to problems in the present).

${ }^{18}$ D. L. Fink (Creating Significant Learning Experiences: An Integrated Approach to Designing College Courses [New York 2003] 48-49) includes caring as one of his six categories of significant learning, because it gives students the energy to learn more, and more deeply. Caring can be about the course content, ideas, the students themselves, others, or learning.

${ }^{19}$ Foster and Yeager (above, n.11); Blake (above n.16); K. L. Riley, "The Holocaust and Historical Empathy: The Politics of Understanding," in Davis, Yeager, and Foster (above, n.12). Davis (above, n.12) 3 analogizes it as an "end-in-view" rather than fulfillment of a destination. 
reception to meet this aim, Michael Broder discusses the resistance of many classics faculty members to encourage students to become agents of social change (despite the increasingly popularity of such a goal among faculty as a whole), because of the potential risk of loss of traditional knowledge. ${ }^{20}$ Barton and Levstik promote teaching historical empathy_including perspective recognition and caring - to further what for them is the optimal goal of students considering problems of justice in the present to ultimately prepare them for engagement in a pluralist democracy. Topics of study should therefore be chosen that "force [students] to consider issues of justice . . . of past events," as part of a larger conversation about how we might avoid such tragedies today and in the future. ${ }^{21}$ The revised course's addition of units on war and slavery-related art helped students consider art that a broad range of people living in the Roman Empire owned, commissioned, or responded to, in relation to justice issues. Such additions made sense to me, especially considering that my school is a Jesuit university with a mission "to develop the creative intellectual potential of its students and to foster in them ethical and religious values and a sense of social responsibility.”22

\section{Examples}

During the units on war and slavery in art, students read, researched, and considered different types of people's relationships to art (patrons, artists, and various viewers) through the artwork's subject matter, style, function, and patronage, using foundational knowledge from the first part of the semester. Using viewer reception theory is a natural way to encourage perspective recognition. John R. Clarke's pioneering Art in the Lives of Ordinary Romans provides a useful chart for ancient viewer reception, as well as case studies on how "ordinary" Romans might have commissioned their own artwork, or viewed imperial monuments. ${ }^{23}$ Analyzing postclassical responses are also useful for both perspective

${ }^{20}$ M. Broder, "Tradition vs. Reception as Models for Studying the Great Books," CW 106.3 (2013) 505.

${ }^{21}$ Barton and Levstik (above, n.17) 38-39, 96-97.

22 "Mission Statement of Fairfield University," Fairfield University, accessed April 10, 2014. http://www.fairfield.edu/aboutfairfield/missionvalueshistory/missionstatement/

${ }^{23}$ J. R. Clarke, Art in The Lives of Ordinary Romans: Visual Representation and Non-Elite Viewers in Italy, 100 BC-AD 315 (Berkeley 2003) 11. 
recognition and pedagogies that value fostering thinking about justice issues. Broder argues that using classical reception to teach ancient literature encourages such thinking, because it changes the focus from purported eternal truths to enduring objects' shifting messages over time, helping to foster "creative and independent thought about such urgent categories as democracy, freedom, and justice" - and the same is true for art. ${ }^{24}$ This section presents specific examples of artworks and readings that can be used in the classroom using this approach.

The Arch of Titus can be addressed with ancient and modern perspective recognition in the classroom to prompt students to analyze the multiple impacts of its aesthetics and its subject. The arch, built after Titus' death in 81 CE by his brother Domitian, is located in a highly visible location on the Via Sacra at the entrance to the Forum, making it an effective case study for viewer reception. Inside the arch are its two often-reproduced reliefs celebrating the conquest of Jerusalem, each 6' 7" tall. One depicts an allegorical version of the triumphal procession, with Titus in a quadriga, crowned by Victory and surrounded by other personifications and figures. The facing relief depicts processing soldiers bearing spoils looted from the Second Temple, including the gold menorah and table of the shewbread. They are among the earliest surviving examples of spatial illusionism in Roman relief sculpture. In art history textbooks, the subject is usually described dispassionately, focusing on its allegorical and stylistic innovations, with little or no discussion of the power of the message it communicated to Roman or later viewers. An exception is in Ramage and Ramage's textbook, which acknowledges that the subject is "one of the darkest days in Jewish history." 25

This monument deserves a deeper analysis of its affective impact, because it was and remains an emotionally charged structure that can be used to help students understand the realities of how "war suffused Roman life to a degree unparalleled in other ancient societies," and prompt them to think how and in what way art worked in concert with

${ }^{24}$ Broder (above, n.20) 505.

${ }^{25}$ N. H. Ramage and A. Ramage, Roman Art (Upper Saddle River, N.J., 2000) 166; many textbooks include a primary text excerpt from Josephus' Jewish War detailing the triumph and describing the spoils that were taken from the temple with little analysis or comment, but omit the section before the spoils where Josephus describes the images of atrocities committed by the Romans that were carried in the parade. 
this suffusion. ${ }^{26}$ Before examining the patron (Domitian) and the (anonymous) artist's subject and style choices (including the recent discovery that the candelabra on the arch was painted gold ${ }^{27}$ ), students who had learned about triumphal arches earlier in the semester could contextualize the monument through critical reading of primary and secondary texts, including Josephus' account of the temple's sacking and the triumph. One can ask students to write about possible reasons why a Roman emperor would depict a scene of triumphal parade rather than combat or subjugated prisoners (as seen on other Roman military monuments), and why the temple implements were carefully depicted in a scene that otherwise is not a faithful historical narrative. The candelabra and shewbread table were not just treasure; they were essential sacred implements from the destroyed center of Jewish worship. Prompting informed thought about how a displaced Jew living in ancient Rome might have responded to this, or a soldier who had participated in a triumph, or a child of a soldier who fought in the campaign, encourages not only a potentially affective connection, but also critical thinking about the nature of political imagery, patronage, monument location, and audience, with regard to the artist's formal choices. I have experienced heightened engagement in the classroom when students explore the different messages conveyed by art and the power it can have on its viewers, as opposed to the previously more static discussion that adheres strictly to the artworks' formal and iconographic qualities.

In addition to considering a spectrum of ancient viewers and their responses to art, incorporating later receptions can also foster historical empathy and caring. Reinforcing the Arch of Titus lesson with discussing modern Jews' avoidance of walking under the arch because of the existence of a ban (purportedly dating from the arch's construction) by Jewish authorities that forbade them from doing so-and the lifting of this ban in 1997-helps students see the sustained authority of the arch's imagery. ${ }^{28}$ Jews' late-antique and later use of the menorah as a symbol,

${ }^{26}$ See K. E. Welch's introduction to Representations of War in Ancient Rome, S. Dillon and K. E. Welch, eds. (New York 2006) 1.

${ }^{27}$ Yeshiva University, "Yeshiva University Team Discovers the Arch of Titus Menorah's Original Golden Color,” June 22, 2012, accessed April 10, 2014. http://yu.edu/cis/ activities/arch-of-titus/

${ }^{28}$ This ban was officially lifted on the fiftieth anniversary of the modern state of Israel's founding. In attendance were the Roman Jewish community and politicians including the Prime Minister of Italy and the Mayor of Rome; see M. Satin, "One Man’s Campaign 
and historical and art-historical reasons why a symbol was necessary, can be incorporated in discussions of justice and freedom.

Recent research on the columns of Trajan and Marcus Aurelius makes these monuments useful in meeting course goals. Not only are they extraordinary achievements of engineering, sculpture, and narrative but the number of scenes and people depicted make them superb case studies of depictions of the human figure, movement, and space. Clarke examines the columns' images of emperors, and prompts his reader to consider "How would the foreigner, slave, and freedman have understood" the visual representations. ${ }^{29}$ Sheila Dillon's article on the depictions of conquered women on the columns was effective for students to learn about the nature of images of war and specifically images versus realities of women during war. ${ }^{30}$ Dillon's thesis is framed by the warning that Roman images of war were not documentary images; they were visual constructs. The Column of Trajan (ca. 180-185 CE), which “depicts" Trajan's campaign in Dacia, does not show images of Roman soldiers committing violence against women, while the Column of Marcus Aurelius (ca. $192 \mathrm{CE}$ ), with the subject of the emperor's campaign against the Germans and Sarmatians, does. Dillon argues that this is not because such violence did not happen in the Dacian wars-in fact, violence against women was standard practice in wartime-but the imagery was intended to communicate that the Roman army, and therefore Trajan, was disciplined and fair. The purpose of the Column of Marcus Aurelius' scenes of soldiers assaulting women was not to faithfully record actual events, but to show a Roman viewer that these threatening Germanic tribes were no longer a danger. Because of the violence against women, their peoples' complete destruction in the present and future was assured. Students analyzed the argument and its evidence

\footnotetext{
Against the Arch of Titus-And How it Changed the Jews," Forward December 1, 2013, accessed March 10, 2014. http://forward.com/articles/188460/one-mans-campaignagainst-the-arch-of-titus-and/?p=all\#ixzz2v8zP5L30. It is a legend that many contemporary Jews are aware of, as is the question of the current location of the temple furnishings depicted on the arch. See S. Fine, " "When I Went to Rome ... There I Saw the Menorah . . . ': The Jerusalem Temple Implements During the Second Century CE," in D. R. Edwards and C. T. McCollough, eds., The Archaeology of Difference: Gender, Ethnicity, Class and the "Other" in Antiquity: Studies in Honor of Eric M. Meyers (Boston 2006) 169-80.

${ }^{29}$ Clarke (above, n.23) 52.

${ }^{30}$ S. Dillon, "Women on the Columns of Trajan and Marcus Aurelius and the Visual Language of Roman Victory," in Dillon and Welch (above, n.26) 244-63.
} 
and construction-scholarship, like art, was never taught as being unquestionable fact.

Dillon's article on the columns was accompanied by sociologist Bridget Byrne's article on issues of gender in military conflict today. ${ }^{31}$ Critical examination of contemporary accounts of related contemporary social issues can help students relate to the Roman material, because few ancient primary texts by the nonelite survive. While "making comparisons between the past and the present is central to efforts to make history relevant and interesting to students," ${ }^{2}$ it can do more; it can prepare students to be engaged citizens. Byrne's or similar readings can be the basis for context and evidence-based discussions on the differences between ancient and modern warfare. For example, violence against women in warfare is often overlooked today because it happens in private spacesyet in antiquity a public monument celebrated it. Byrne's argument of how war impacts men and women differently resonates with Dillon's thesis in various ways; rape is used as a military weapon in both ancient and recent conflicts because women are often symbolic bearers of culture and of ethnic and national identity; therefore the rape of women is an act of aggression against a nation or community that is intended to demoralize. ${ }^{33} \mathrm{~A}$ writing assignment that asks students to compare and contrast the authors' arguments, formally analyze a scene of their choice from another triumphal arch or victory monument, and propose how a variety of individuals in Rome, including subjected ones, might respond to the imagery, will promote higher-order thinking and deeper learning than regurgitation of received facts.

Imagery related to childhood in the Roman Empire was another topic in the slavery unit that considered the nonelite and noncitizens along with issues of justice. We looked at objects, including ancient toys, and funerary altars and reliefs with images of commemorated elite and nonelitechildren. The Roman degree of commemoration of children in funerary monuments was unparalleled until twentieth-century Western cultures, and it supports the idea that freeborn Roman children were valued in society, as educational practices and child-related religious

${ }^{31}$ B. Byrne, "Towards a Gendered Understanding of Conflict," IDS Bulletin 27 (1996) 31-40.

${ }^{32}$ K. Yilmaz, "A Vision of History Teaching and Learning: Thoughts on History Education in Secondary Schools,” HSJ 92 (2008) 44.

${ }^{33}$ Byrne (above, n.31) 33. 
ritual and medical treatment also show. ${ }^{34}$ Like the representations of the conquered, those of children are not snapshots; they all have symbolic meanings. Students analyzed images and interpretations. A case study was the Relief of Servilli, a late first-century BCE tomb façade fragment depicting a freeborn son and his manumitted (per the inscriptions) parents. The child is clearly differentiated from the adults not only by his age and Q.f inscription, but compositionally - an engaged column separates the child from the adults - and through the emphasis on the bulla around his neck. Students proposed that the former slaves are promoting the free status of their child, who will belong to a different society and have different opportunities than they did. ${ }^{35}$ Asking them to think like a patron (social status, gender, occupation, and age of their choice) and design their own tomb relief helps meet the goals of applying and appreciating the course material, as they are creating and researching a persona in which they are presumably interested, and must carefully look at and absorb subjects and styles of other funerary monuments in order to design one that has historical and visual accuracy (an important component of the grade).

Students read an article by Sarah Currie and excerpts from Jeannine Diddle Uzzi's book on images of children, both of which examine official images of Roman versus barbarian children on different monuments, and how children's bodies were used symbolically to represent notions of Romanness and empire. Roman monuments use images of free Roman children, consistently depicted with fathers or male figures and female divinities, to express the empire's prosperity, stability, and hope for the future. ${ }^{36}$ In contrast, subjected non-Roman children are usually shown as submissive, and with their mothers or other female figures; the opposite of a future hope for their people. Reading the arguments in light of previous discussions of the use of gender on public monuments helps students make connections between the material and helps them model their own art-historical thinking.

To facilitate students' perspective recognition of viewers and makers of such imagery, and to encourage caring about injustices to enslaved and

${ }^{34}$ B. Rawson, Children and Childhood in Roman Italy (Oxford 2003) 363.

${ }^{35}$ F. Kleiner, A History of Roman Art (Farmington Hills, Mich., 2010) 82-83.

${ }^{36}$ S. Currie, "The Empire of Adults: The Representation of Children on Trajan's Arch at Beneventum," in Art and Text in Roman Culture, J. Elsner, ed. (Cambridge 1996) 153-81; J. D. Uzzi, Children in the Visual Arts of Imperial Rome (Cambridge 2005). 
subjected children so remote in time and place to their own childhoods, I assigned the latest United Nations report on the status of children in countries currently engaged in conflict. ${ }^{37}$ In class we also watched the documentary Not My Life, which treats the trafficking of children into slavery in Asia, Africa, and North America. ${ }^{38}$ To compare this with contemporaneous art, we also looked at a slideshow from photographer James Mollison's book, Where Children Sleep, depicting portraits of children around the world from varying economic strata juxtaposed with scenes of their bedrooms or sleeping spaces, and the possessions contained therein. ${ }^{39}$ Examining images of children affected by war, human trafficking, and/or slavery, and hearing their own narratives, brings closer what ancient conquered and slave children endured, while raising awareness of the suffering of many children in the world today.

It is crucial in class to evaluate the contemporary imagery as critically as we do the Roman, and responsibly. The contemporary material should also be grounded in evidence and contextualized. How do the artistic choices of the director or photographer convey a message, and what is the message? For whom is the message intended? Students raised the point that some of the American children profiled in the documentary did not fulfill the definition of "slave" that we had discussed in class, and it was useful to ask and postulate why the director included that segment, as well as review definitions of slavery, while discussing his aesthetic choices and how they impacted the film. After seeing the images of children and their sleeping spaces, students engaged with the photographers' choices of subject and compositions, resulting in a good debate as some found the depictions exploitative, while others found them moving. When considering the circumstances of those less fortunate than the average American college student, one should avoid writing or discussion prompts that promote feelings of superiority or gratitude for one's own good fortune, rather than true empathy. ${ }^{40} \mathrm{H}$. James Garret and Kyle Greenwalt warn, in terms of historical empathy, "Indeed, it all too often strengthens the

${ }^{37}$ United Nations General Assembly, Report of the Special Representative of the Secretary-General for Children and Armed Conflict, accessed January 25, 2012. http:// childrenandarmedconflict.un.org/library/.

${ }^{38}$ Not My Life, Dir. Robert Bilheimer, Worldwide Documentaries, 2011.

${ }^{39}$ K. McDonald, “'Where Children Sleep”” New York Times, August 4, 2011, accessed January 25, 2012. http://lens.blogs.nytimes.com/2011/08/04/where-childrensleep/; J. Mollison, Where Children Sleep (London 2011).

${ }^{40}$ Davis (above, n. 12) 3 observes that historical empathy is not sympathy, or any kind of appreciative sentiment. 
divisions between self and other-that which we least want it to do." ${ }^{41}$ Not only do we not want it to foster an "us-versus-them" division, but we also do not want the only take-away to be feelings of relief on the part of the students that they are from relative privilege. A student reflected on the importance of empathy in the course:

This class was unique in comparison to the majority of the art history courses I have taken over the past four years because of its humanitarian element that links the subject to the real world. In many ways that has allowed the course to be more beneficial, not in just teaching students about the art from ancient Rome, but also to show how art really matters.

\section{Conclusion}

It is hard to measure or assess lifetime goals of empathy or increased civic engagement within the class. By expanding the scope of material studied and intentionally integrating multiple perspectives on art, and reading about contemporary human consequences of war and slavery, there was more energy and enthusiasm in the class, and more informed discussion (because students found the reading topics interesting, they actually read them). Students had the option of integrating contemporary humanitarian concerns into their final object-based research papers, the topics of which they chose during a class trip to the Metropolitan Museum of Art, or of writing a more traditional art history paper focusing on inquiry of the object in its ancient context. Research projects that included a humanitarian component were creative, as well as methodologically and historically sound. For example, in a paper on a pair of silver scyphi decorated with cupids in relief, the student effectively conveyed not only their rarity and beauty as appreciated today, and how they might have been appreciated by those drinking from them two millennia ago, but also the potential responses of the servants who would have cleaned, polished, and served the vessels. She also examined the means by which the silver was mined, and the toll that mining took on the mostly subject peoples who performed the work, hypothesizing using the health effects of silver-mining in the modern period (since no ancient data is available). Her research was presented at the national JUHAN conference the following summer. Now that I know what students are capable of, I look

\footnotetext{
${ }^{41}$ Garret and Greewalt (above, n.16) 4.
} 
forward to challenging them further in the next iteration of the course. Using components of historical empathy and real-world events within a Roman art history course renewed my own enthusiasm for teaching it, and I believe helped inspire the students to better appreciate and understand Roman art and civilization, and to care more than before about the effects of both art and human action on others.

FAIRFIELD UNIVERSITY

MRose@fairfield.edu

Appendix

Sample Course Schedule:

UNIT 1: INTRODUCTION TO ROMAN ART (WEEKS 1-6)

Topics: Etruscan and Early Italian Art

Roman Republic: Temples and Public Works

Roman Republic: Domestic Architecture and Decoration

Roman Republic: Portraiture

Roman Empire: Temples, Fora, and Public Works

Roman Empire: Houses

Roman Empire: Domestic Architecture and Decoration

Roman Empire: Portraiture

Roman Empire: Funerary Art

UNIT 2: THE ROMAN ART OF WAR (WEEKS 7-8)

Topics: Triumphs and Triumphal Monuments

Women in War

Children in Ancient Rome

Use of Art for Healing during War Today

UNIT 3: SLAVERY AND ART (WEEKS 9-12)

Topics: Slaves and Funerary Art

Slaves in Domestic Art

Freedmen in Roman Art and Archaeology

Human Trafficking and Art Today

UNIT 4: MAINTAINING POWER THROUGH PROPAGANDA (WEEKS 13-14)

Topics: The Art of Roman Spectacle

Art of the Roman Provinces

Imperial Portraiture in the Late Empire

READINGS

The historical scholarship on ancient slavery is too extensive to include here. Listed sources are art-historical, or historical with significant use of images. 
Roman Art

R. Brilliant, “'Let the Trumpets Roar': The Art of Roman Triumph,” in The Art of Ancient Spectacle, B. Bergmann and C. Kondoleon, eds., (Washington, D.C., 1999) 221-29.

S. Brown, "Death as Decoration: Scenes from the Arena on Roman Domestic Mosaics," in Pornography and Representation in Greece and Rome, A. Richlin, ed., (Oxford 1991) 180-211.

J. R. Clarke, Art in The Lives of Ordinary Romans: Visual Representation and Non-Elite Viewers in Italy, 100 BC-AD 315 (Berkeley 2003).

S. Currie, "The Empire of Adults: The Representation of Children on Trajan's Arch at Beneventum," in Art and Text in Roman Culture, J. Elsner, ed., (Cambridge 1996) 153-81.

E. D’Ambra, Roman Art (Cambridge 2006).

E. D’Ambra, Roman Women (Cambridge 2007).

P. De Souza, "War, Slavery, and Empire in Roman Imperial Iconography." BICS 54, (2011) 31-62.

S. Dillon, and K. E. Welch, eds., Representations of War in Ancient Rome (New York 2006).

M. George, ed., Roman Slavery and Roman Material Culture (Toronto 2012).

S. Joshel, Slavery in the Roman World (Cambridge 2010).

F. S. Kleiner, A History of Roman Art, Enhanced Edition (Boston, 2010).

D. Mattingly, Imperialism, Power, and Identity: Experiencing the Roman Empire (Princeton 2011).

L. H. Peterson, The Freedman in Roman Art and Art History (Cambridge 2006).

F. Pirson, "Style and Message on the Column of Marcus Aurelius," Papers of the British School at Rome 64 (1996) 139-79.

Ramage, N. and A. Ramage, Roman Art (Upper Saddle River N.J. 2014).

R. Rodgers, "Female Representation in Roman Art: Feminizing the Provincial 'Other," in Roman Imperialism and Provincial Art, S. Scott and J.Webster, eds. (New York 2003) 69-93. 
M. Rose, "The Construction of Mistress and Female Slave Relationships in Late Antique Art,” WAJ 30 (2008) 41-49.

S. Scott, and J. Webster, eds., Roman Imperialism and Provincial Art (Cambridge 2003).

P. Stewart, Social History of Roman Art (Cambridge 2008).

Tuck, Steven L., A History of Roman Art (Chichester 2015).

J. D. Uzzi, Children in the Visual Arts of Imperial Rome (Cambridge 2005).

\section{Contemporary Art and Issues}

B. Byrne, "Towards a Gendered Understanding of Conflict," IDS Bulletin 27 (1996). 31-40.

K. Hefling, "Female Soldiers Raise Alarm on Sexual Assaults," NBCnews.com. Updated July 21, 2008. http://www.nbcnews.com/id/25784465/ns/us_newsmilitary/t/female-soldiers-raise-alarm-sexual-assaults/\#.VVYMh0a3oxI

P. M. Knapp, “The Rwanda Healing Project,” segdDesign (2006) 40-43.

J. Lee, “Art Show Shines Light on Sex Trafficking's Victims,” New York Times, November 10, 2009. http://cityroom.blogs.nytimes.com/2009/11/10/art-showshines-light-on-sex-traffickings-victims/?_r=0

H. Martinez, "Colombia: Sexual Violence as a Weapon of War," Inter Press Service, October 21, 2009. http://ipsnews.net/news.asp?idnews=4894

R. Bilheimer, dir., Not My Life (Worldwide Documentaries 2011).

L. Smith-Spark, "How Did Rape become a Weapon of War?” BBC News, August 12, 2004. http://news.bbc.co.uk/2/hi/4078677.stm

United Nations General Assembly, Report on Children and Armed Conflict (New York 2010). http://www.securitycouncilreport.org/un-documents/childrenand-armed-conflict/

United Nations Office on Drugs and Crime, "Combating Human Trafficking Through Collective Action and Art," May 11, 2009. http://www.unodc.org/ unodc/en/frontpage/combating-human-trafficking-through-collective-actionand-art.html 